\begin{tabular}{l} 
POLITEIA/ POLITEIA: Jurnal Ilmu Politik \\
Politeia, 12 (1) (2020): 80-96 \\
ISSN 0216-9290 (Print), ISSN 2549-175X (Online) \\
Available online https:/ / talenta.usu.ac.id/politeia \\
\hline
\end{tabular}

\title{
Menggugat Hegemoni Demokrasi: Disciplinary Power Demokrasi di Negara Dunia Ketiga
}

\author{
Bagus Riadi*
}

Departemen Ilmu Politik, Universitas Padjajaran, Bandung, 45363, Indonesia

Submitted: 7 February 2020 Revision: 31 Mei 2020 Accepted : 13 July 2020

\begin{abstract}
Abstrak
Munculnya istilah Dunia Ketiga, Negara Berkembang, dan Utara-Selatan tampaknya menjadi konsep untuk memisahkan negara baik dan negara jahat. Istilah ini dikonsumsi oleh komunitas Dunia Ketiga dan membangkitkan tubuh yang kita tinggali di negara di mana kondisinya tidak seharusnya seperti ini. Keterbukaan informasi dan komunikasi melalui globalisasi membuat Dunia Ketiga mulai mengenal demokrasi. Kondisi ekonomi negara Dunia Ketiga yang buruk, akhir Perang Dingin, dan runtuhnya Tembok Berlin menjadi serangkaian peristiwa yang menjadikan demokrasi sah sebagai kebenaran. Sehingga tercipta kelompok pro-demokrasi di Dunia Ketiga yang memaksa negara menerapkan demokrasi. Ditambah dengan kehadiran indikator demokrasi untuk menilai negara-negara demokratis dan tidak demokratis, membuat negara-negara Dunia Ketiga berlomba-lomba untuk mengambil indikator untuk menjadi negara paling demokratis. Ini menunjukkan bahwa demokrasi sudah diyakini sebagai rezim kebenaran. Demokrasi di Dunia Ketiga diikuti oleh kapitalisme yang pada akhirnya memperburuk kondisi di negara-negara Dunia Ketiga, sehingga negara-negara Dunia Ketiga terperangkap dalam kapitalisme global. Menggunakan konsep Michel Foucault, hegemoni demokrasi akan digambarkan sebagai wacana yang menciptakan kekuatan disiplin bagi masyarakat Dunia Ketiga untuk dapat menerima demokrasi dan percaya pada demokrasi sebagai kebenaran.
\end{abstract}

Kata Kunci: Kekuasaan Pendisiplinan, Demokrasi, Dunia Ketiga, Kapitalisme, Negara Berkembang

\begin{abstract}
Abstrak
The emergence of the terms Third World, Developing Countries, and North-South seemed to be a concept to separate the good country and the bad country. The term is consumed by the Third World community and awakens to the body that we live in a country where conditions are not supposed to be this way. Disclosure of information and communication through globalization makes the Third World begin to recognize democracy. The poor Third World state economic conditions, the end of the Cold War, and the collapse of the Berlin Wall became a series of events that made democracy legitimate as a truth. So as to create a pro-democracy group in the Third World that forces the state to implement democracy. Coupled with the presence of democratic indicators to assess democratic and undemocratic countries, making Third World countries vying to take the indicator to become the most democratic country. This shows that democracy is already believed to be a truth regime. Democracy in the Third World is followed by capitalism which ultimately exacerbates conditions in Third World countries, so that Third World coutries are caught in global capitalism. Using the concept of Michel Foucault, the hegemony of democracy will be described as a discourse that creates disciplinary power for Third World societies to be able to accept democracy and believe in democracy as a truth.
\end{abstract}

Keywords: Disciplinary Power, Democracy, Third World, Capitalism, Developing Countries

How to Cite: Riadi, B. (2020). Menggugat Hegemoni Demokrasi: Disciplinary Power Demokrasi di Negara Dunia Ketiga. Politeia: Jurnal Ilmu Politik, 12 (1): 80-96.

*Corresponding author:

E-mail: bagusbr11@gmail.com 


\section{PENDAHULUAN}

Istilah "Dunia Ketiga" digunakan untuk merujuk negaranegara yang baru muncul setelah berakhirnya Perang Dunia II yang berakhir pada tahun 1945. Secara akademis, istilah Dunia Ketiga baru ditemukan pada tahun 1950-an untuk menunjuk sekelompok negara-negara yang secara ekonomis lemah dan terbelakang, yaitu negara-negara yang didekolonisasikan di Afrika, Asia, dan Timur Tengah, dan juga negaranegara Amerika Latin, yang negaranegara tersebut kebanyakan memperoleh kemerdekaanya pada abad ke-19 dan abad 20 (Haynes, 1997).

World Trade Organization (WTO) memberi rumusan bila menyebut negara berkembang diartikan sebagai negara yang perekonomiannya hanya mampu mendukung standar kehidupan yang rendah dan masih dalam tahap awal pembangungunan. Konsep ekonomi-politik negara berkembang pada umumnya adalah Non-blok, yakni negara-negara yang tidak berpihak dalam persaingan Timur dan Barat. Negara dunia ketiga adalah negara yang dimana kondisi ekonominya kurang menguntungkan atau kurang baik. Sistem ekonomi negara dunia ketiga berada diluar sistem ekonomi Barat (Kapitalis) yang disebut negara Dunia Pertama, dan diluar sistem ekonomi Timur (Sosialis) yang disebut negara dunia kedua (Rudy, 2004).

Negara maju dan negara berkembang sering juga diistilahkan dalam konsep Utara-Selatan. Utara termasuk negara-negara yang berpenduduk $1 / 4$ dari jumlah penduduk dunia dan menikmati $80 \%$ dari penghasilan penduduk dunia. Selatan, yaitu negara-negara berkembang yang juga negara dengan jumlah penduduk yang padat yakni 3/4 dari jumlah penduduk dunia, tetapi hanya menikmati sekitar 20\% dari penghasilan penduduk dunia. Terdapat kesenjangan yang besar antara Utara dan Selatan. Salah satu penyebab kesenjangan ini adalah ketika dimulainya imperialisme dan kolonialisme negara-negara Eropa yang masuk ke negara-negara dunia ketiga (Rudy, 2004). Imperalisme dan kolonialisme Eropa tersebut pada akhirnya membawa kapitalisme Barat 
Bagus Riadi, Menggugat Hegemoni Demokrasi: Disciplinary Power Demokrasi di Negara Dunia Ketiga.

untuk menancapkan akarnya pada negara-negara jajahannya yang berada di Timur.

Kapitalisme

kembali menguatkan akarnya pada saat terjadi Revolusi Industi yang dimulai di Inggris. Berkat penemuan mesinmesin produksi pada akhirnya tenaga manusia mulai ditinggalkan karena dianggap tidak efisien. Istilah Revolusi Industri menggambarkan kemajuan pesat yang terjadi berkat pemanfaatan teknik produksi manufaktur sejak abad XVII, khususnya pada tahun 1770 (Jessua, 2015). Sejak terjadi revolusi industri ini maka bangsa Eropa semakin gencar menguatkan cengkeramannya pada negara dunia ketiga yang juga merupakan negara penghasil komoditas industri. Saat itu juga tejadi perlawanan oleh kaum buruh dikarenakan pemilik modal memperkerjakan manusia sebagai tenaga-tenaga kasar. Wanita dan anak-anak kecil dipekerjakan dengan waktu yang lama tetapi dengan gaji yang kecil, tentunya ini tidaklah sebanding. Kondisi ini memunculkan perlawanan buruh terhadap pemilik modal.
Sejak terjadi kesenjangan antara negara maju dan negara berkembang, timbul anggapan bahwa kesenjangan di dunia adalah akibat kapitalisme, tetapi bukan karena kapitalisme telah memiskinkan kelompok-kelompok tertentu, tetapi karena mereka yang menerapkan kapitalisme menjadi kaya. Distribusi kekayaan yang tidak merata di dunia disebabkan oleh tidak meratanya distribusi kapitalisme (Norberg, 2001). Anggapan tersebut memunculkan fenomena demokratisasi di berbagai penjuru dunia, seolah-olah demokrasi mengklaim bahwa jika negara ingin maju dan ikut bersaing di era globalisasi maka harus menjadi negara demokratis yang menjunjung tinggi kebebasan yang didalamnya juga terdapat konsep pasar bebas. Akibatnya negara-negara di dunia berlomba-lomba untuk menjadi negara yang demokratis. Hal ini diperkuat pasca perang dingin dimana terjadi polarisasi antara blok barat dan blok timur. Blok barat adalah kapitalis, dan blok timur adalah sosialis. Perang dingin ini berakhir dengan kemenangan blok barat yang mengagungkan konsep 
demokrasi liberal diikuti dengan kapitalismenya. Pernyataan ini diperkuat dengan tulisan Francis Fukuyama dalam bukunya The End History and The Last Man, yang dengan berani menyatakan bahwa sejarah dunia telah berakhir dengan kemenangan demokrasi liberal (Fukuyama, 2005). Seperti kita ketahui bahwa demokrasi liberal diikuti dengan embel-embel kapitalisme.

Masalah utama yang terjadi di negara berkembang adalah negara berkembang kekuarangan modal untuk melakukan pembangunan ekonomi di negaranya. Pada umumnya, hutang dan beban cicilannya dianggap menyulitkan usaha pembangunan di negara berkembang. Negara berkembang cenderung untuk memperoleh dana dengan menarik masuknya investasi asing. Hal ini merupakan pilihan yang setengah terpaksa. Walaupun disisi lain fenomena ini disebut sebagai arah baru dalam perkembangan dunia (Rudy, 2004).

Pada saat ini dapat kita lihat dan rasakan semakin banyak perusahaanperusahaan asing yang bercokol di negara-negara berkembang. Negara berkembang sudah dikonstruksi oleh demokratisasi, konsep kebebasan, pasar bebas dan lain sebagainya. Sehingga memudahkan perusahaan asing untuk dapat masuk ke Indonesia. Negara berkembang merupakan sasaran investasi negara maju dikarenakan harga komoditi dan upah tenaga kerja di negara berkembang jauh lebih murah dibandingkan dengan di negara maju. Oleh karenanya negara-negara maju mulai mengekspansi negara-negara berkembang dan dari sini kapitalisme mulai bercokol di negara-negara berkembang.

Melalui teori diskursus yang dikembangkan oleh Michel Foucault, tulisan ini akan menjelaskan fenomena demokratisasi di Dunia Ketiga sehingga demokratisasi tersebut dapat menyuburkan hegemoni kapitalisme di Dunia Ketiga. Fenomena demokratisasi yang menyebar secara luas di berbagai belahan dunia, khususnya pada akhir abad 20 yang kemudian di klaim oleh Francis Fukuyama bahwa demokrasi liberal adalah akhir dari perjalanan panjang umat manusia akan dikupas melalui pendekatan relasi 
Bagus Riadi, Menggugat Hegemoni Demokrasi: Disciplinary Power Demokrasi di Negara Dunia Ketiga.

pengetahuan dan kekuasaan yang hegemoni. Maka menurut Foucault dikemukakan oleh Michel Foucault. hegemoni adalah mutlak, manusia Dalam tulisan ini akan dijelaskan hidup dalam hegemoni, dan manusia bagaimana proses beroperasinya menerima hegemoni tersebut sebagai kekuasaan melalui pengetahuan sebuah kenormalan. Sehingga masyarakat Dunia Ketiga akan hegemoni tersebut sering dianggap demokrasi, bahwa demokrasi adalah sebuah kebenaran, dan kita menerima sebuah kebenaran yang harus kebenaran tersebut (Foucault, 2012). diyakini dan diterima, sehingga Dalam hal ini, demokrasi dalam demokrasi dijadikan sebagai tujuan perspektif Foucault adalah bentuk yang kemudian fenomena pengetahuan yang kita miliki. demokratisasi ini diikuti oleh Masyarakat abad ke-21 melihat kemuculan kapitalisme negara maju demokrasi adalah sebuah hal yang di negara Dunia Ketiga. Dari biasa, demokrasi sudah menjadi pembahasan tersebut nantinya akan hegemoni dalam benak setiap didapat kesimpulan bahwa apakah manusia di abad ke-21. Bahkan pengetahuan manusia selalu bersifat negara-negara yang sebelumnya politis ataukah tidak selamanya "didakwa" tidak demokratis bersifat politis.

Menurut Foucault, kekuasaan tersebar terdapat dalam setiap pikiran manusia. Kekuasaan dalam pikiran kita tersebut adalah yang berlomba-lomba untuk menjadi negara yang demokratis melalui upaya demokratisasi. Negara-negara tersebut tidak lain adalah negara Dunia Ketiga. Melalui perjalanan mendisiplinkan kita. Kekuasaan panjang tersebut masyarakat Dunia dalam pikiran kita didapat dari Ketiga ikut mempercayai bahwa pengetahuan yang kita miliki. Dari demokrasi adalah sebuah kebenaran. pengetahuan tersebut kita disiplinkan Namun, belakangan diketahui bahwa oleh pengetahuan untuk menjadi upaya demokratisasi seolah-olah normal. Manusia selalu mencoba dijadikan kendaaraan bagi untuk menjadi normal, ke-normalan kapitalisme untuk dapat memperluas tersebut tercipta dari sebuah cengkeramannya memasuki Dunia 
Ketiga. Menanggapi fakta tersebut yang dikembangkan oleh Michel masyarakat Dunia Ketiga seakan Foucalt.

menerima fakta tersebut dan kemudian semakin mempercayai

HASIL DAN PEMBAHASAN

bahwa kapitalisme yang diboncengi Label Negara Dunia Ketiga

oleh demokratisasi merupakan jalan Istilah "Dunia Ketiga" satu-satunya untuk mencapai ditemukan pada tahun 1950-an untuk kesejahteraan negara Dunia Ketiga. Hegemoni tersebut akan dibongkar menggunakan teori diskursus oleh Michel Foucault, bahwa bagaimana pengetahuan tersebut beroperasi menguasai pikiran masyarakat Dunia Ketiga sehingga dapat didisiplinkan oleh pengetahuan tersebut.

\section{METODE PENELITIAN}

menunjuk pada sekelompok besar (negara) yang secara ekonomi terbelakang, yaitu negara-negara yang didekolonisasikan di Afrika, Asia, dan Timur Tengah dan, di pihak lain, pada negara-negara Amerika Latin, kebanyakan yang mendapatkan kemerdekaanya di abad ke-19, tetapi secara ekonomi masih lemah (Haynes, 1997).

Penelitian ini dilakukan dengan menggunakan kualitatif-diskursus. Melalui metode diskursus penelitian ini akan mengupas makna kekuasaan yang terdapat dalam pengetahuan "demokrasi". Makna-makna tersebut akan digali menggunakan pendekatan genealogi Michel Foucault. Data-data yang dipaparkan dalam penelitian ini diperoleh melalui studi literatur. Data yang telah diperoleh kemudian diintrepretasikan oleh peneliti dengan berpegang pada teori dan metode

Namun demikian tidak semua negara Dunia Ketiga memiliki tingkat ekonomi yang rendah. Terdapat perbedaan di antara negara Dunia Ketiga itu sendiri seperti misalnya dalam aspek ekonomi terdapat negara yang tingkat ekonominya cukup tinggi seperti Uni Emirat Arab (PNB 1993 per kapita \$21.430), Korea Selatan (\$7.660), berbeda dengan Mozambique contohnya dengan pendapatan perkapita \$90. Selain perbedaan di pada aspek ekonomi, terdapat juga perbedaan aspek politis 
Bagus Riadi, Menggugat Hegemoni Demokrasi: Disciplinary Power Demokrasi di Negara Dunia Ketiga.

antara negara Dunia Ketiga seperti Kuba (negara komunis satu partai), Nigeria (kediktatoran militer), berbeda dengan India contohnya menentukan sebuah negara dapat dengan pemerintahan demokrasi multi partai (Haynes, 1997). Namun bagi sebagian orang perbedaan ekonomi dan politik tersebut mengaburkan istilah Dunia Ketiga, sehingga istilah Dunia Ketiga digunakan untuk membuat generalisasi bahwa negara Dunia Ketiga seluruhnya adalah negaranegara yang baru merdeka dan memiliki tingkat ekonomi yang rendah.

Selain penggunaan istilah Dunia Ketiga, terdapat juga pengkaburan istilah "Utara-Selatan" atau "negara berkembang". Istilah Selatan merujuk pada negara-negara yang terbelakang secara ekonomi dan mayoritas letak geografisnya berada di Selatan garis khatulistiwa. Namun pada kenyataanya bahwa beberapa negara yang tingkat ekonominya maju seperti Jepang dan Korea Selatan tidak benarbenar berada di "Selatan" secara geografis.

Istilah negara berkembang juga merupakan sebuah label Barat untuk menggolongkan negara-negara yang masih berkembang secara ekonomi. Terdapat sejumlah indikator yang dikatakan negara maju. Pada umumnya negara maju adalah negara-negara yang memiliki tingkat ekonomi yang tinggi dilihat dari sejumlah indikator yang ditetapkannya. Seperti dijelaskan sebelumnya bahwa konsep ekonomipolitik negara berkembang pada umumnya adalah Non-Blok yakni tidak memihak Barat ataupun Timur dalam persaingan hegemoni antara Barat (kapitalis) dan Timur (Komunis). Istilah Barat juga merepresentasikan Amerika Serikat, dan Timur merepresentasikan Uni Soviet selama masa Perang Dingin. Persaingan tersebut pada akhirnya dimenangkan oleh Barat ditandai dengan berakhirnya Perang Dingin dan runtuhnya tembok Berlin pada 1989 yang memisahkan antara Berlin Barat (pro Amerika) dan Berlin Timur (pro Uni Soviet).

Istilah-istilah tersebut dikonsumsi oleh pikiran kita sebagai masyarakat Dunia Ketiga, sehingga pembangunan dan pertumbuhan 
kita dibuat yakin bahwa kita adalah masyarakat Dunia Ketiga dengan segala situasi dan kondisinya seperti yang digambarkan. Selain itu, terciptanya indikator yang membedakan negara maju dan negara berkembang juga membuat negaranegara berkembang berlomba-lomba untuk mencapai indkator terebut demi mendapat lebel prestise sebagai negara maju. Istilah-istilah tersebut bekerja sebagai disiplinary power yang beroperasi terhadap tubuh untuk mengendapkan normalisasi kekuasaan sebagai proses pembiasaan dalam tubuh terhadap perilakunya dan menempatkan tubuh kita sebagai kendaraan bagi kekuasaan tersebut (vehicle of power).

Definisi-definisi ilmiah secara jelas juga menunjukkan efek beroperasinya kekuasaan dalam bentuk rezim wacana. Foucault menjelaskan bahwa definisi psikiatri tentang mental mengubah pratik penanganan orang gila. Definisi kedokteran tentang penyakit, menyebabkan isolasi, pengasingan, dan mengubah hubungan sosial. Konsep tentang kecantikan menghasilkan salon, diet, cara makan, fitnes, pakaian, dan kursus-kursus. Hal ini menunjukkan bahwa sebuah definisi ilmiah dapat menunjukkan pemaknaan tentang bagaimana kita harus menghadapi realitas tersebut. Seperti definisi tentang Dunia Ketiga atau negara berkembang memberikan pandangan demokrasi pada masyarakat Dunia Ketiga.

\section{Diskursus Demokrasi}

Munculnya demokratisasi di Dunia Ketiga diawali karena adanya kesadaran definisi ilmiah yang akhirnya beroperasi sebagai kekuasaan dalam tubuh masyarakat Dunia Ketiga, sehingga definisi ilmiah tersebut bertindak sebagai disciplinary power dalam tubuh. Pendisiplinan demokratisasi dalam tubuh masyarakat Dunia Ketiga tidak muncul secara tiba-tiba, terdapat serangkaian peristiwa pembenaran terhadap demokratisasi sehingga masyarakat Dunia Ketiga benar-benar meyakini bahwa demokrasi adalah sebuah kebenaran. Pada akhirnya klaim kebenaran tentang demokrasi beropeasi pada tubuh kita.

Seperti yang telah dipaparkan sebelumnya, negara Dunia Ketiga 
Bagus Riadi, Menggugat Hegemoni Demokrasi: Disciplinary Power Demokrasi di Negara Dunia Ketiga.

merupakan negara yang beru saja karena data yang dirilis oleh World mendapatkan kemerdekannya, Bank merupakan pertumbuhan ratasehingga secara ekonomi masih rata, tetapi kecenderugannya dapat lemah. Selama 1960-an dan awal 1970- dilihat bahwa negara di Asia Timur an angka pertumbuhan ekonomi di 'rata-rata' berhasil mencapai seluruh wilayah Dunia Ketiga pertumbuhan ekonomi tahunan seragam sekitar 3 persen setahun perkapita antara 1980 dan 1993 (Callaghy 1993, dikutip oleh Jeff sebesar 8,8 persen, lebih baik daripada Haynes 1997).

Tabel 1 Pertumbuhan rata-rata tahunan PDB per kapita menurut wilayah, 1980-1993

\begin{tabular}{cc}
\hline Wilayah & \% pertumbuhan \\
\hline Asia Timur dan & 6,4 \\
Pasifik & \\
Asia Selatan & 3,0 \\
Amerika Latin dan & $-0,1$ \\
Karibia & \\
Afrika Sub-Sahara & $-0,8$ \\
Timur Tengah dan & $-2,4$ \\
Afrika Utara & \\
\hline
\end{tabular}

Haynes 1997).

Sumber: World Bank 1995: 163, tabel 1. DIkutip oleh Jeff Haynes 1997: 91

Selama 1980-an seperti yang digambarkan pada tabel 1.1, terdapat ketimpangan dalam pertumbuhan ekonomi pada wilayah negara-negara Dunia Ketiga seperti berikut: Wilayah Asia Timur dan Pasifik berjalan paling baik, sedangkan Timur Tengah dan Afrika Utara paling buruk. Namun data tersebut dapat menjadi kabur negara-negara di Timur Tengah dan Afrika Utara (Callaghy dan Ravenhill 1993, dikutip oleh Jeff Haynes 1997).

Pertumbuhan ekonomi yang buruk tersebut kemudian mendapatkan desakan dari rakyat yang menuntut perbaikan kehidupan. Keadaan ekonomi yang suram tersebut memungkinkan terbukanya ruang demokrasi bagi masyarakat Dunia Ketiga, yang menurut Haynes (1997) demokrasi diawali oleh tekanan dari kelompok aksi di Dunia Ketiga. Salah satu katalisator kemunculan kelompok aksi tersebut adalah kemunduran makroekonomi dan gerakan global ke arah demokrasi.

$$
\text { Menurut Haynes }
$$
sejumlah pemerintah Dunia Ketiga tidak demokratis. Perubahan sistem demokrasi secara formal di Amerika Latin dan sebagian Asia dan Afrika sub-sahara adalah akibat dari tekanan 
internasional maupun dalam negeri. Telah diterima secara luas bahwa tekanan internasional membantu meyakinkan kebanyakan pemerintah Dunia Ketiga yang nondemokratis untuk mengadakan pemilihan yang kompetitif (Bratton, 1994; Moore, 1995; Pridham, 1994; Samuel, 1991).

Pada 1996, 23 negara Amerika Latin secara formal beralih menjadi demokratis, sementara 7 (dari 20) yang sebelumnya adalah negara otoriter di Asia seperti Bangladesh, Mongolia, Nepal, Pakistan, Filipina, Korea Selatan, dan Taiwan juga menjadi negara demokrasi (Potter, 1993). Di Afrika sub-sahara makin banyak rezim yang dipilih: lebih dari separo dari 48 negara di wilayah tu mengadakan pemilihan umum selama 1989-1996 (Wiseman, 1995). Hanya di Timur Tengah yang tampak hanya sedikit gerakan demokrasi, meskipun terdapat tanda-tanda yang menggembirakan: di Lebanon, demokrasi telah diperkenalkan kembali setelah 20 tahun, Jordan melaksanakan pemilihan umum yang cukup "bebas dan adil" pada tahun 1994, dan sejumlah orang Palestina mengalami gerakan-gerakan sementara menuju otonomi di Daerah Pendudukan Israel (Haynes, 1997).

Persetujuan Helsinski menjadi faktor munculnya kelompok prodemokrasi di Eropa Timur yang pada akhirnya mendorong jatuhnya rezim komunis. Menurut pandangan Hutington, kemajuan demokrasi Dunia Ketiga didorong oleh gabungan perkembangan dalam negeri dan global. Dalam kaitannya dengan perkembangan global, yang penting adalah runtuhnya pemerintahan komunis di Eropa Timur, sehingga menempatkan pemerintah nondemokratis di Dunia Ketiga di bawah tekanan yang kuat untuk mengadakan reformasi dan mendorong kaum demokrat yang menginginkan hal itu. Chilton (1995) sebagaimana dikutip oleh Haynes (1997) menyatakan bahwa kematian politis Uni Soviet dan sistem komunis beserta sekutusekutunya dalam Pakta Warsawa yang tidak terjadi secara tiba-tiba sangat berpengaruh untuk menempa kaum demokrat yang mendambakannya di Dunia Ketiga. Maka muncul efek demokratisasi dari runtuhnya Tembok Berlin pada 1989. Menurut Fukuyama, hal ini 
Bagus Riadi, Menggugat Hegemoni Demokrasi: Disciplinary Power Demokrasi di Negara Dunia Ketiga.

dikarenakan hilangnya tantangan dari kontrahegemoni, yaitu komunis, terhadap demokrasi liberal dan kapitalisme merupakan faktor pelicin untuk meyakinkan negara Dunia Ketiga bahwa demokrasi adalah satusatunya jalan yang harus dilalui, dan oleh karenanya demokrasi mulai mendapat legitimasi di Dunia Ketiga. Selain itu, Randall (1993) menyatakan bahwa kemampuan menembus komunikasi internasional adalah berpengaruh dalam mendorong kecenderungan demokratisasi di Dunia Ketiga.

Tiga perkembangan penting yakni: runtuhnya Tembok Berlin dan hancurnya pemerintahan komunis di Eropa Timur; tekanan diplomatik dan ekonomi oleh pemerintah negaranegara Barat dan organisasi pemerintahan internasional; dan diciptakannya iklim demokrasi yang didukung oleh revolusi komunikasi. Sehingga rangkaian tersebut memunculkan kelompok prodemokrasi di Dunia Ketiga (Haynes, 1997). Kelompok-kelompok ini kemudian yang mendesak pemerintahannya untuk beralih menjadi demokratis diawali dengan menghimbai negara untuk menyelenggarakan pemilihan umum yang demokratis.

Serangkaian peristwa tersebut pada akhirnya meyakinkan tubuh untuk dapat menerima demokrasi yang dianggap sebagai sebuah kebenaran. Menurut Michel Foucault, suatu pengetahuan dari masa ke masa bukan suatu perkembangan yang evolutif, melainkan sebagai pergeseran dari satu bentuk pengetahuan ke bentuk pengetahuan lain yang otoritatif pada masa tertentu sebagai sebuah rezim wacana (Mudhoffir, 2013). Dalam Archeology of Knowledge, Arkeologi oleh Foucault digunakan untuk menangkap apa yang disebut Foucault sebagai episteme. Episteme merupakan bentuk pengetahuan yang telah dimantapkan sebagai pemaknaan terhadap situasi tertentu pada suatu zaman tertentu.

Demokrasi sebagai episteme adalah sebuah pengetahuan sekaligus kekuasaan yang legitimate mempengaruhi praktik-praktik sosial individu, baik cara berpikir, berbicara, maupun bertindak sebagai sebuah rezim pengetahuan. Demokrasi 
hanyalah sebuah kebenaran yang dapat diterima saat ini yang mana pada rezim pengetahuan saat ini sedang dipegang oleh demokrasi sebagai sebuah episteme. Hal ini berarti demokrasi telah beroperasi dalam tubuh sebagai sebuah kekuasaan. Melalui serangkaian peristiwa yang telah dipaparkan, demokrasi menjadi legitimate bertolak dari suatu bentuk pengetahuan tentang demokrasi itu sendiri, yakni konsep-konsep atau pernyataanpernyataan yang terorganisasi secara sistematis sehingga menjadi otoritatif dan legitimate.

Pemantapan demokrasi sebagai episteme menjadi legitimate terjadi pada level wacana (discourse). Demokrasi sebagai sebuah rezim wacana merupakan bentuk dari kekuasaan. Wacana dapat berwujud sebagai praktik-praktik yang mengorganisasikan dan terorganisasikan, wacana tersebut mengubah konstelasi sosial dan yang menghasilkan, dan wacana sebagai yang memiliki otonomi dan klaim atas kebenaran dan kontekstualisasi sebuah pengetahuan. Oleh karenanya, menurut Foucault tidak ada suatu kebenaran atau pengetahuan benar yang final dan bersifat universal. Itu berarti demokrasi bukanlah sebuah pengetahuan yang final seperti yang diklaim oleh Francis Fukuyama dalam The End History and The Last Man.

Klaim kebenaran demokrasi itu merupakan bentuk beroperasinya kekuasaan sebagai suatu wacana yang mempengaruhi institusi-institusi sosial dan praktik-praktik sosial. Wujud kekuasaan yang dalam hal ini adalah demokrasi adalah tidak nampak, maka beroperasinya demokrasi sebagai sebuah kekuasaan menjadi tidak disadari dan memang tidak dirasakan oleh individu sebagai praktik kekuasaan yang sebenarnya mengendalikan tubuh individu dalam masyarakat Dunia Ketiga. Dengan demikian setiap masa memiliki watak pengetahuan yang khas dan definisi kebenaran yang khas pula.

\section{Demokratisasi dan Kapitalisme}

Rezim kebenaran demokrasi tersebut pada akhirnya memunculkan fenomena demokratisasi di berbagai penjuru Dunia, khususnya negara Dunia Ketiga. Ditambah lagi dengan adanya revolusi komunikasi 
Bagus Riadi, Menggugat Hegemoni Demokrasi: Disciplinary Power Demokrasi di Negara Dunia Ketiga.

sebagaimana yang telah dipaparkan sebelumnya, sehingga memunculkan fenomena globalisasi dengan gagasan "dunia tanpa batas". Sehingga masyarakat dunia dapat bertukar informasi dan komunikasi dengan sangat mudahnya. Maka penguatan klaim kebenaran demokratisi semakin terbentuk.

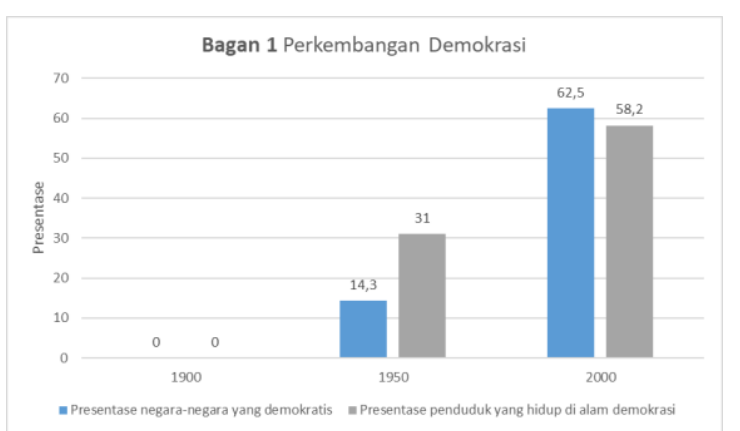

Sumber: Freedom House, 2000, "Democracy's Century: A Survey of Global Political Change in the 20th Century: (New York: Freedom House, 2000), Dikutip oleh Johan Norberg 2001:24

Dari bagan tersebut dapat dilihat bahwa trend demokrasi mengalami kenaikan dalam satu abad ini. Negaranegaa dan masyarakatnya di dunia semakin yakin bahwa demokrasi adalah suatu tujuan dalam bernegara. Demokrasi seakan menjadi akhir dari tujuan masyarakat dunia. Bahkan diciptakan ukuran demokratisasi untuk menilai sebuah negara demokratis atau tidak dengan sejumlah indikator tertentu. Sehingga negara Dunia Ketiga berlomba-lomba untuk mencapai indikator tersebut demi mendapat gelar negara terdemokratis. Padahal apa masalahnya jika sebuah negara tidak demokratis tetapi dapat menciptakan kesejahteraan bagi rakyatnya. Setidaknya diklaim oleh Norberg (2001) bahwa jumlah peperangan dalam sepuluh tahun terakhir telah berkurang hingga separuhnya. Menurutnya hal ini dikarenakan bahwa negara-negara demokrasi tidak saling berperang satu sama lain. Selain itu, adanya pertukaran internasional membuat konflik kehilangan daya tariknya. Tambahnya lagi, kesejahteraan tidak diperoleh dengan cara mencaploki wilayah milik bangsa lain, melainkan melalui perdagangan dengan daerah tersebut beserta sumber dayanya.

Benar bahwa demokrasi memungkinkan adanya pertukaran internasional sehingga dapat menjalin komunikasi yang cukup erat antar negara dalam dunia internasional. Hal ini memang membuat negara-negara menjadi segan untuk memulai konflik, sehingga peperangan dan konflik 
internasional menjadi berkurang. hendak menanamkan modalnya di Namun, faktanya masalah yang negara Dunia Ketiga disambut baik terjadi bukan pada dunia oleh negara berkembang tersebut. Hal internasional. Masalah yang ini dikarenakan salah satu masalah ditimbulkan oleh demokratisasi negara berkembang adalah berlangsung pada level domestik kekuarangan modal untuk terutama dalam negara Dunia Ketiga. melaksanakan pembangunan di Masyarakat Dunia Ketiga yang masih negaranya. Dengan di iming-imingi awam terhadap demokrasi secara sejumlah imbalan akibatnya negara tidak langsung dipaksa untuk dapat berkembang tidak dapat menolak menerima demokrasi dalam investasi asing. Padahal, hampir kehidupannya, sehingga hal ini separuh dari profit perusahaan asing menimbulkan masalah sosial baru di tersebut dimiliki oleh mereka, negara Dunia Ketiga yang ditimbulkan oleh berkembang hanya mendapat sedikit demokrasi. Seperti kemiskinan, kriminalitas, kesenjangan sosial, dan lain sebagainya.

Selain itu, demokrasi juga diikuti dengan adanya kepitalisme dari negara-negara maju. Mereka berusaha men-demokratisasi negara Dunia Ketiga untuk dapat mencengkeram negara Dunia Ketiga melalui penanaman modalya di negara Dunia Ketiga, ini merupakan sebuah kolonialisme gaya baru. Sehingga pernyataan bahwa antar negara demokrasi dapat hidup damai dan makmur karena adanya pertukaran internasional nyatanya tidak benarbenar terjadi. Perusahaan asing yang

kompensasi

melaksanakan untuk dapat sementara perusahaan asing dapat bercokol puluhan tahun lamanya, bahkan lebih.

Masalah kesenjangan ekonomi di negara berkembng dalam Dunia Ketiga diklaim oleh Norberg (2001) bahwa hal tersebut dikarenakan kapitalisme yang tdak merata. "Kesenjangan di dunia adalah akibat kapitalisme. Bukan karena kapitalisme telah memiskinkan kelompok-kelompok tertentu, tetapi karena mereka yang menerapkan kapitalisme menjadi kaya. Distribusi kekayaan yang tidak merata di dunia 
Bagus Riadi, Menggugat Hegemoni Demokrasi: Disciplinary Power Demokrasi di Negara Dunia Ketiga.

disebabkan oleh tidak meratanya syaratnya adalah negara harus kapitalisme (Norberg, 2001). menggunakan sistem good governance Pernyataan tersebut menghipnotis dalam penyelenggaraan masyarakat dunia untuk menerima pemerintahannya. Sistem tersebut kapitalisme, meyakinkan bahwa kita memungkinkan kelompok harus menerima kapitalisme demi masyarakat untuk dapat terlibat kemakmuran bersama. Namun pada dalam proses kebijakan yang hendak kenyataanya, semakin negara berkembang membuka kapitalisme kepada dunia semakin sumber daya alam negara berkembang habis dkeruk asing. Memang negara berkembang mendapatkan imbalan atas sambutannya terhadap kapitalisme global, namun imbalan tersebut tidak sebanding dengan apa yang telah dilepaskan begitu saja kepada perusahaan asing.

Pada akhirnya negara berkembang tetap saja kekurangan modal untuk melaksanakan pembangunan. Defisit pada negara berkembang memaksanya untuk mengajukan utang luar negeri, yang diajukan kepada IMF (International Monetary Fund) dan Bank Dunia. IMF (International Monetary Fund) tidak begitu saja mencairkan dana bagi negara berkembang. Negara-negara yang hendak mengajukan utang harus memenuhi beberapa syarat. Salah satu dibuat oleh pemerintah. IMF memaksa negara debitur untuk menerapkan sistem tersebut sebagai jaminan untuk negara debitur agar dapat membayar utangnya di masa yang akan datang. Namun negara berkembang tetap saja mengalami kekurangan modal karena defisit, sehingga terus menerus memaksanya mengajukan utang luar negeri. Akibatnya utang yang lama belum terbayar namun terus menambah utang baru, sehingga negara berkembang lama kelamaan terlilit utang-utangnya.

Masalah-masalah di negara berkembang sedemian banyaknya sehingga hal ini menjadi kesultian tersendiri bagi negara berkembang untuk menetapkan prioritas masalah mana yang akan diselesaikan. Ketika berusaha untuk menyelesaikan masalah yang satu masalah yang lain akan datang dan akan memperburuk 
keadaan yang lainnya. Sehingga hal ini menjadi dilematis bagi negara berkembang. Akibatnya negara berkembang tidak akan mungkin menjadi negara maju, karena pada hakikatnya negara berkembang sudah dikonstruksi oleh negara maju dan berada dalam cengkeraman negara maju. Tidak akan mungkin bagi negara berkembang memperbaiki nasibnya sampai rezim pengetahuan demokrasi runtuh dan berganti menjadi rezim yang baru.

\section{SIMPULAN}

Demokrasi hanyalah sebuah rezim kebenaran pengetahuan yang sedang berjaya pada saat ini. Kita tidak pernah tahu kapan rezim kebenaran tersebut akan runtuh digantikan dengan pengetahuan yang baru. Klaim Fukuyama bahwa demokrasi adalah akhir dari perjalanan panjang umat manusia sangat naif.

Kita tidak akan pernah tahu apa yang akan terjadi di depan. Memang demokrasi pasca Perang Dingin kehilangan kontra hegemoni, sehingga demokrasi menjadi rezim pengetahuan yang dipercaya sebagai kebenaran pada zaman ini. Fenomena demokratisasi yang terjadi di Dunia Ketiga menunjukkan bagaimana beroperasinya pengetahuan sebagai kekuasaan dalam tubuh, sehingga mendisiplinkan tubuh untuk menjadi normal dalam bayang-bayang demokrasi. Apalagi diciptakan serangkaian indikator untuk menjadi negara demokrasi, akibatnya negara berlomba-lomba untuk menjadi negara paling demokratis.

Indikator tersebut menciptakan suatu standar penormalan, maka negara yang tidak mencapai indikator tersebut akan dianggap tidak normal. Fakta selanjutnya adalah demokrasi sebetulnya juga digunakan sebagai alat bagi negara maju untuk dapat mencengkeram negara-negara berkembang demi kepentingan industri. Usaha-usaha kapitalisme untuk menancapkan cengekeramannya pada negara berkembang tentunya dapat diteliti lebih lenjut.

Pemerintah negara berkembang melalui serangkaian kabijakannya tanpa disadari berpihak kepada kapitalisme global. Maka negara berkembang akan tetap menjadi 
Bagus Riadi, Menggugat Hegemoni Demokrasi: Disciplinary Power Demokrasi di Negara Dunia Ketiga.

negara berkembang selama rezim kebenaran demokrasi masih

beroperasi sebagai kuasa dalam setiap tubuh masyarakat dunia. Hal ini menunjukkan bahwa pengetahuan selalu bersifat politis.

\section{DAFTAR PUSTAKA}

Bratton, M. (1994). Civil society and political transition in Africa. Institute for Development Research Boston, MA.

Foucault, M. (2012). Arkeologi Pengetahuan. In IRCiSoD. Yogyakarta.

Fukuyama, F. (2005). Akhir Sejarah. In G. Roose (Ed.), Amerika dan Dunia (pp. 1-34). Jakarta: Yayasan Pustaka Obor Indonesia.

Haynes, J. (1997). Demokrasi E Masyarakat Sipil di Dunia Ketiga. Jakarta: Yayasan Pustaka Obor Indonesia.

Jessua, C. (2015). Kapitalisme. Terjemahan Rosana Hariyanti, Yogyakarta, Jalasutra.

Moore, M. (1995). Democracy and development in cross- national perspective: A new look at the statistics. Democratization, 2(2), 1-19.

Mudhoffir, A. M. (2013). Teori kekuasaan Michel Foucault: Tantangan bagi sosiologi politik. Jurnal Sosiologi Masyarakat, 75-100.

Norberg, J. (2001). Membela Kapitalisme Global. Jakarta: Friedrich-Naumann-
Stiftung fur die Frehiet.

Potter, D. (1993). Democratization in Asia. Prospects for Democracy: North, South, East, West, 355-379.

Pridham, G. (1994). Democratic Transitions in Theory and Practice. Democratization in Eastern Europe, pp. 15-37. London: Routledge.

Randall, V. (1993). The media and democratisation in the Third World. Third World Quarterly, 14(3), 625-646.

Rudy, T. M. (2004). Masalah Negara Berkembang: Suatu Kajian EkonomiPolitik Internasional. Bandung: Penerbit Bina Budhaya.

Samuel, H. (1991). The third wave: Democratization in the late twentieth century. Norman. University of Oklahoma.

Wiseman, J. A. (1995). Democracy and political change in Sub-Saharan Africa. Psychology Press. 